\title{
IAMJ
}

INTERNATIONAL

AYURVEDIC

MEDICAL JOURNAL

\section{EFFECT OF KUNJAL KRIYA AND AGASTYA HARITKI RASAYANA IN TAMAKA SHWASA W.S.R BRONCHIAL ASTHMA: A CASE STUDY}

\author{
Neerja R. Sharma ${ }^{1}$ Hemant Kumar ${ }^{2}$ \\ ${ }^{1}$ Dept. of Swasthavritta and Yoga, Shri Dhanvantari Ayurvedic College, Chandigarh, India \\ ${ }^{2}$ Ayurvedic Medical Officer, Govt. Ayurvedic Hospital Ludhiana, Punjab, India
}

Corresponding Author: hemantpatialvi@gmail.com

\section{https://doi.org/10.46607/iamj4009122021}

(Published Online: December 2021)

Open Access

(C) International Ayurvedic Medical Journal, India

Article Received: 14/11//2021 - Peer Reviewed: 07/12/2021 - Accepted for Publication 08/12/2021

\section{Check for updates}

\begin{abstract}
Tamaka Shwasa (Bronchial asthma) is one of the stressful medical conditions of today's era and is well known for its episodic and chronic course which affects the whole human race. Tamaka shwasa is a disease in which the patient experiences severe symptoms of respiratory distress with extreme weakness, fatigue and mental glooming. Tamaka Shwasa can be correlated with the disease Bronchial Asthma based on its features \& etiopathogenesis. Here the sincere effort has been made using Kunjal kriya a shodhana chikitsa and Agastya Haritaki as Rasayana. Rasayana plays an important role in the rejuvenation of body tissues and providing strength to patients. A male patient of Age 40 years with a history of Tamaka shwasa from last 5 years. The Patient has all classical symptoms like Shwasakashtata, Kasa, Kaphashteevan, Aruchi, Parshvashula, Asino Labhate Saukhyam, Ghurghuraka comes at O.P.D of Govt. Ayurvedic Hospital Model Gram Ludhiana, On Auscultation of chest wheezing present bilaterally in lungs. The patient was using short-acting Bronchodilator puffs almost 3-4 puffs in a day. So, this case of Tamaka shwasa is treated with Kunjal Kriya a Yogic Shodhana Karma once a week followed by Rasayana for four weeks. All this was done after examination of Bala of the Patient. In this case, it was observed patient got good relief in all cardinal symptoms of Tamaka shwasa.
\end{abstract}

Keywords: Rasayana, Kunjal Kriya, Tamaka Shwasa 


\section{INTRODUCTION}

Bronchial Asthma is a major global health problem, which can affect the population irrespective of age, sex, economic status, etc. Asthmatic problem is increasing day by day due to environmental smoke and air pollution resulting from urbanization. Tamaka Shwasa (Bronchial Asthma) is a disorder of Pranavaha in which vitiation of kapha \& vata dosha occurs mainly and its origin is pitta sthana. The causative factors of Shwasa roga are described as Raja (Dust), Dhumavata (Smoke-Wind), Shitasthana, Shitaambu, Vyayama (Exercise), and mainly caused by Vata and Kaphadosha. There are five types of Shwasaroga mentioned in Ayurveda are MahaShwasa, Urdhva Shwasa, Chinna Shwasa, Tamaka Shwasa and Kshudra Shwasa. Tamaka shwasa is one among them and it is predominantly vatakaphaja vyadhi, The disease Tamaka Shwasa is predominantly caused by Pranavaha Sroto Dusti and in its pathogenesis, Pratiloma Gati of Vata plays an important role along with Srotorodha produced by Kapha, Vitiated Kapha in the Uraha Pradesha (chest region) obstructs the normal path of Vata, This further leads to Avaranajanya Vata Prakopa and Pratiloma Gati of Vata which can be stated as Kapha dominant pathogenesis of Tamaka Swasa. At the initial stage, it is said to be Sadhya (curable) and in chronic cases, it is Yapya (Manageable). Tamaka swasa is characterized by dyspnoea (Swasakrichrata), chest tightness (Ura shula), wheeze (Gurgaruktvamhm) and cough (kasa). Kunjal Kriya eliminates the excess of Kapha dosha which is the main cause of the increase in congestion in the lungs, bronchitis, cold, and cough. This cleansing procedure is easy to perform, cost-effective, good result oriented and very effective to cure the etiological factor responsible for Tamak shawas. Agastaya haritiki was planned as Rasayan which is continued for four weeks. Shodhana is an essential part of any Rasayana therapy, to remove Avarana. The maximum content of Agastya haritki possesses vata-kapha shamak property. So present study has been designed which was to evaluate the efficacy of Kunjal Kriya and Shodhana Kriya and Agastya Haritaki as Rasayana in the management of Tamakashwasa (Bronchial Asthama).

Material and Method:

Source of Data: Patient suffering from symptoms of Tamaka Shwasa selected from O.P.D of Govt. Ayurvedic Hospital Model Gram Ludhiana Punjab.

Study Design: A single case study

Duration of study: Total Duration 28 days, Kunjal Kriya was done once a week for four weeks and Agastya Rasayan given $5 \mathrm{gm}$ twice a day with warm water after food for four weeks

\section{A Case Report.}

A male patient of Age 40 years having classical symptoms like Shwasakashtata, Kasa, Kaphashteevan, Aruchi, Parshvashula, Asino Labhate Saukhyam, Ghurghuraka with a history of Tamaka shwasa from last 5 years

History of present illness: The patient was well before 5-year, the problem started gradually when the patient noticed the dust allergy, Patient had taken Initially some home remedies and got mild relief but with time condition was getting worsened.

History of Treatment: He was taking treatment from a local physician who had given steroids and antihistamine drugs to the patient, then he started to take treatment from the civil hospital Ludhiana, where he was put on short-acting Bronchodilator puffs. The patient had taken many homoeopathy and allopathic medications but could not get relief. There is no history of Diabetic Mellitus, Hypertension, Epilepsy, Tuberculosis, Anemia etc.

\section{Personal History}

Occupation: Labour class

Addiction: H/o Smoking, Tobacco Chewing from last 10 years

Ahar: Mostly irregular diet, Hotel food, Oily, Spicy, Fast food.

Family History: The patient grandfather was also suffering from Tamaka shwasa.

\section{Ashtavidh Pariksha :}

Nadi: Vat kaphaj Mutra: Sam, Mala: Sam, Jivha:

Sam Shabda: Kriccha bhashitamha, Sparsha; Khara, Druka: Prakritika, Akruti: Sthula 


\section{On Examination}

\section{Systemic Examination}

RS: On Auscultation wheezing was observed Bilaterally in the lungs.

Respiration Rate -22/min

CVS: No e/o any murmur

B.P 130/80 $\mathrm{mm}$ of $\mathrm{Hg}$, Pulse $-76 / \mathrm{min}$

CNS: Conscious well oriented to Time, Place and Person.

P/A: Soft, No tenderness, No Organomegaly.

Lab Investigations:

Blood: TLC -5000mm3, DLC - N 70\%, L 25\%, E $5 \%$ B 0\%, $\mathrm{Hb} \%-13.5$ gm, ESR-15mm in $1^{\text {st }}$ Hour.

Radiological examination: X-ray chest: e/o pulmonary hyperinflation, bronchial wall thickening present.

Pulmonary function test: Peak flow meter test yellow zone $50 \%$ to $80 \%$

\section{Procedure:}

\section{1) Kunjal Kriya}

Elephant uses the Kunjal Kriya to eliminate the contents from his trunk, in the same manner, humans do the Kunjal Kriya to eliminate the contents from their stomach.
Material: The water will be lukewarm with salt.

Posture: The person has to sit in Kagasana and then they have to drink the water. During the expulsion of water, it is best to stand and bend forwards keeping the trunk and head horizontally.

Time: The best time to do the practice is early in the morning, before Sunrise, After the Kunjal Kriya don't eat anything for half an hour.

Procedure: Kunjala Kriya is performed by drinking lukewarm, salty water, at least an average of six glasses of water should be drunk, but if you can, drink more up to the point where you cannot take even one more sip, at this point you may vomit automatically, if not then put two fingers down your throat and massage the back of your tongue as far down as possible. Water will come out of your mouth in a quick series of gushes.

Shaman chikitsa: After Shodhana Agastaya Haritaki rasayana $5 \mathrm{gm}$ with warm water started after food twice a day for four weeks.

Treatment Follow up: Kunjal Kriya was done once a week for four weeks and Agastya Rasayan was given $5 \mathrm{gm}$ twice a day with warm water after food for four weeks.

Criteria for Assessment of Results: Assessment criteria before and after treatment was taken from which significant improvement were noted.

\begin{tabular}{|c|c|c|c|c|c|}
\hline Sr No & Parameters & G0 & G1 & G2 & G3 \\
\hline 1 & Breathlessness & Absent & Mild while walking & $\begin{array}{l}\text { While at rest -Prefer } \\
\text { sitting }\end{array}$ & While at rest-Sits Upright \\
\hline 2 & Wheeze & Absent & $\begin{array}{l}\text { Moderate only at end of } \\
\text { Expiration }\end{array}$ & $\begin{array}{l}\text { Loud throughout Expi- } \\
\text { ration }\end{array}$ & $\begin{array}{l}\text { Loud throughout inhalation } \\
\text { \& Expiration }\end{array}$ \\
\hline 3 & $\begin{array}{l}\text { Frequency } \\
\text { Shwasa vega }\end{array}$ & Absent & $\begin{array}{l}\text { Symptoms lasting for }<1 \\
\text { hour }\end{array}$ & $\begin{array}{l}\text { Symptoms lasting for } \\
1-3 \text { hours }\end{array}$ & $\begin{array}{l}\text { Symptoms lasting for more } \\
\text { than } 1-3 \text { hour }\end{array}$ \\
\hline 4 & Cough & Absent & After exercise & $\begin{array}{l}\text { Continuous disturb } \\
\text { work }\end{array}$ & $\begin{array}{l}\text { Continuous disturb the nor- } \\
\text { mal activity }\end{array}$ \\
\hline 5 & Sputum & Absent & Only in morning & 4-5 times a day & continuously \\
\hline 6 & Chest Tightness & Absent & mild & moderate & severe \\
\hline 7 & Pulse Rate & $<80$ & $80-100$ & $100-120$ & $>120$ \\
\hline 8 & Respiration Rate & $18-23$ & $24-30$ & $31-40$ & $>40$ \\
\hline 9 & $\begin{array}{l}\text { Peak Expiratory } \\
\text { Flow Rate }\end{array}$ & $>80 \%$ & $70-80 \%$ & $61-70$ & $<60$ \\
\hline
\end{tabular}




\section{DISCUSSION}

The disease Tamaka Shwasa is predominantly caused by Pranavaha Sroto Dusti and in its pathogenesis is Pratiloma Gati of Vata plays an important role along with Srotorodha produced by Kapha, Vitiated Kapha in the Uraha Pradesha (chest region) obstructs the normal path of Vata (Prana), This further leads to Avaranajanya Vata Prakopa and Pratiloma Gati of Vata which can be stated as Kapha dominant pathogenesis of Tamaka Swasa. Kunjal Kriya is a Shodhan karma especially for Kapha dosha which is the main cause for Tamaka shwasa, the strong contractions made by the pyloric sphincter which produce a shock wave along with the vagus nerve release spasm within the bronchial tree. Kunjala Kriya produces instant relief for an asthma attack. Kunjal Kriya expels out also the vitiated Pitta Dosha in the state of Acchadita from the Amashaya and as a result, Jatharagni becomes normal. The Ama formation and other sequential events thus are restricted by the Kunjala Kriya and ultimately stop further pathogenesis of Tamaka shwasa.

\section{Outcome Assessment in Tamakashwasa}

\begin{tabular}{|l|l|l|l|}
\hline Sr no & Parameters & Before Treatment & After Treatment \\
\hline 1 & Breathlessness & 2 & 0 \\
\hline 2 & Wheeze & 2 & 1 \\
\hline 3 & Frequency of swasvega & 2 & 0 \\
\hline 4 & Cough & 2 & 1 \\
\hline 5 & Sputum & 2 & 0 \\
\hline 6 & Chest Tightness & 1 & 0 \\
\hline 7 & Pulse Rate & 2 & 0 \\
\hline 8 & Respiratory rate & 1 & 0 \\
\hline 9 & Peak Expiratory flow rate & 1 & 0 \\
\hline 10 & Total Score & 15 & 2 \\
\hline
\end{tabular}

Agastaya haritiki is given $5 \mathrm{gm}$ twice a day with warm water after food for four weeks. Shodhana is an essential part of any Rasayana therapy, to remove Avarana. The maximum content of Agastya haritki possesses vata-kapha shamak property. During Rasayana kala Pathya- Apathya was advised to avoid curd, banana, Diwaswapan na and all garishtha drava bhojana during Rasayana sevana, which also helps in Tamak swasa. It was observed in this case, that patient gets improvement in all its parameters. The total score before treatment is 15 and after treatment of four weeks score i.e 2, So there is a significant improvement in all Parameters. During treatment, there was no complication appeared

\section{CONCLUSION}

There are many treatment modalities for Tamaka Shwasa.Here an effort was made to show the effect of Kunjal Kriya as Shodhana Kriya and Agastaya Haritaki Rasayana on Tamakashwasa. In this case, it is proved that Shodhana followed by Rasayana is a good line of treatment in Tamaka shwasa.

\section{REFERENCES}

1. Ravi Dutt Tripathi Charak Samhita 'Vaidya Manorama Hindi Commentary' Vol.1, Chaukhamba Sanskrit Pratishthan, Punarmudrit Sanskaran, Edt. Reprint2011, Chikitsa Sthana 17/55-60,71-73.

2. Dr Bramhanand Tripathi, 'Ashtang Hridayam of Srimadvagbhata' Edited with 'Nirmala Hindi commentary' Chaukhamba Sanskrit Pratishthan Delhi, Reprinted- 2013, Nidan sthana 4/6-10.

3. The Ayurvedic Formulary of India, Part 1, Second edition, Government of India,

4. Ministry of Health and Family Welfare, Department of Indian system of Medicine

5. and Homeopathy, New Delhi, page 33.

6. The Gheranda samhita, Editor Rai Bahadur Srisa Chandra Vasu, Its Edition, Chaukhambha Sanskrit Pratishthan, Delhi, 2003; ghe. San. 1/35-40. 
7. Swami Muktibodhananda Hathyogapradipika- 'Light on Hatha yoga' Yoga publication trust, Ganga Darshan, Munger, Bihar.Edt.3rd-1998, Reprinted 2006.

8. Prof. M. S. Baghel, 'Developing Guidelines for Research Methodology in Ayurveda, Gujarat Ayurveda University, 2011.

9. Davidson, Principles and practice of Medicine, 13th chapter, 19th edition- 1995, Published by Lewington, Page- 513.

10. Harrison principles of internal medicine, Vol-2, 17th edition- 2008 published by India Mcgraw hill, New York, Page- 1596.

11. www.scholar.google.com

12. www.researches-in-Ayurveda.co.in

\section{Source of Support: Nil \\ Conflict of Interest: None Declared}

How to cite this URL: Neerja R. Sharma \& Hemant Kumar: Effect Of Kunjal Kriya And Agastya Haritki Rasayana In Tamaka Shwasa W .S.R. Bronchial Asthma: A Case Study. International Ayurvedic Medical Journal \{online\} 2021 \{cited December 2021\} Available from: http://www.iamj.in/posts/images/upload/3169 3173.pdf 